\title{
Pre-service English language teachers' perceptions towards teaching grammar
}

\author{
Mohan Singh Soud \\ Tribhuvan University, Nepal
}

\begin{abstract}
This article explores the perceptions of pre-service English language teachers studying at Master's level under Education faculty at Tribhuvan University Nepal towards grammar and grammar teaching employing a qualitative research design. Three preservice English teachers were involved in this study, out of which two were females and one was male. The research participants were interviewed using a semi-structured interview technique to collect relevant information to fulfill its purpose. The findingsreveal that pre-service English teachers are in favour of teaching grammar. However, they believe that grammar should not be taught giving rules directly. All of the participants favour the use of inductive method of teaching grammar though they were taught through the use of deductive method at school.
\end{abstract}

Keywords: Grammar teaching, pre-service teachers, inductive method, deductive method, constructivism

\section{Introduction}

The teaching of grammar continues to be a matter of controversy in the field of language teaching. English language teaching and learning consists of different skills and aspects. English grammar is one of the aspects of teaching English language. Grammar teaching has held and continues to hold a central place in language teaching. "Grammar gains its prominence in language teaching, particularly in English as a foreign language (EFL) and English as a second language (ESL), in as much as without a good knowledge of grammar, learners' language development will be severely constrained" (Widodo,
2006, p.122). The role of grammar and how to integrate it into foreign language classroom are at the core of ESL and EFL learning and teaching context (Ellis, 2001, as cited in Uysal\& Yavuz, 2015, p.1828). "Grammar is an instrument to form meaningful sentences" (Thornbury, 1999) of English language. Therefore, grammar teaching is taken as "an indispensable part of English Language Teaching (ELT)" (Uysal\& Yavuz, 2015).

Larsen-Freeman (2003) claims 'grammaring' as 'the fifth skill' (alongside listening, speaking, reading, and writing).By grammaring, she means "the ability to use grammar structures accurately, meaningfully, and 
appropriately" (p. 143). Grammar lessons are no longer about knowing language systems (declarative knowledge), but about knowing how to use language (procedural knowledge). Cross (1991) defines grammar as "the body of rules which underlie a language. This includes rules which govern the structure of words and which govern the structure of clauses and sentences 'that are acceptable to educated native speakers" (as cited in Dikici, 2012, p.207).

Grammar is fundamental to language and is an indispensable component of any language teachingprogramme. Therefore, the teaching of grammar is essential if students are to develop confidence in their ability to use language in various social and educational settings. Grammar is seen as "an essential, inescapable component of language use and language learning" (Burgess \& Etherington, 2002, as cited in Dikici, 2012, p.207). Formal grammar teaching helps learners to acquire second language (L2) more rapidly and get higher level of achievement. Practically, in the teaching of grammar, learners are taught rules of language commonly known as sentence patterns. According to Ur (1999), in the case of the learners, grammatical rules enable them to know and apply how such sentence patterns should be put together. For most teachers, the main idea of grammar teaching is to help learners internalise the structures taught in such a way that they can be used in everyday communication (Ellis, 2002, p.168). The teaching of grammar should ultimately centre attention on the way of using grammatical items or sentence patterns correctly. In other words, teaching grammar should encompass language structure or sentence patterns or forms, meaning and use (Larsen-Freeman, 2001). "The ultimate goal of teaching language is to provide the students with knowledge of the way language is constructed so that when they listen, speak, read and write, they have no trouble applying the language that they are learning" (Widodo, 2006). So the importance of teaching grammar cannot be underrated as Long and Richards (1987) add that "it cannot be ignored that grammar plays a central role in the four language skills and vocabulary to establish communicative tasks" (as cited in Widodo, 2006, p.122).

However, recently there has been lots of debate about grammar in language teaching and learning. As Thornbury (1999) says, "Grammar teaching has always been one of the most controversial and least understood aspects of language teaching" (p. ix). One controversy or issue is whether to teach or not teach grammar. As Lakhoua (2004) says" From grammar translation to the communicative approach, to grammar in use and functional grammar, grammar teaching has ebbed and flowed going from banning its explicit teaching, to teaching it as a communicative tool, to teaching it explicitly in an instructional way". "With the advent of the Communicative Approach in ELT, grammar has been marginalized as the focus has shifted from accuracy to" (Lakhoua, 2004) fluency and communicative competence. Some linguists like Krashen (1982) argue that formal instruction in grammar will not contribute to the development of 'acquired' knowledge. Others, however, have argued that grammar teaching does help in learning and acquiring language (Ellis, 2002; Larsen-Freeman, 2003; Ur, 1999; Thornbury, 1999; Doff, 2000; Cowan, 2008). Doff (2000) says that by learning grammar students can express meanings in the form of phrases, clauses and sentences. According to Ellis (2002), "formal grammar teaching has a delayed rather than instant effect" (p.167). "Usually debates about grammar often lie at the heart of various methodological orientations whether grammar should be taught inductively/ deductively" (Dikici, 2012) or "implicitly/ explicitly" (Rahman, \& Rashid, 2017). 
Despite the debates on teaching grammar, English grammar has been taught from school level to even Master level in the context of our country. This is perhaps due to the importance of teaching grammar for the consolidation of English language. In this regard, Mart (2013) says, "To be an effective language user, learners should study grammar because grammar skills will help learners to organize words and messages and make them meaningful" (p.124). In another idea about why teaching grammar is important, Ellis (2006) writes that"grammar teachinginvolves any instructional technique that draws learners' attention to some specific grammatical form in such a way that it helps them either to understand it metalinguistically and/or process it in comprehension and/or production so that they can internalize it" (as cited in Burgo, 2015). As Richards and Rynandya (2002) state:

In recent years, grammar teaching has regained its rightful place in the language curriculum. People now agree that grammar is too important to be ignored, and that without a good knowledge of grammar, learners' language development will be severely constrained.(p.145)

This saying also highlights the importance of teaching English grammar. As an English language teacher, I have been teaching English from plus two level to Master's level. So my interest here is to explore how pre-service Englishlanguage teachers perceive teaching English grammar at school level in the context of Nepal despite the role of grammar as one of the most controversial issues in language teaching. Here, in my study, pre-service teachers refer to those who are studying English education at universities and who have not involved in the real classroom teaching profession yet.

\section{Research Questions}

The present study aims to explore the preservice English language teachers' perceptions on grammar instruction by looking for answers of the following questions:

1. How do the pre-service teachers perceive teaching English grammar?

2. How do they think grammar should be taught and why?

3. Why do they think that grammar should be taught in language teaching?

\section{Literature Review}

As grammar teaching is a controversial issue (Lakhoua, 2016), research on teachers' beliefs about grammar instruction has gained prominent importance (Capan, 2014). Here, teachers' belief is taken synonymously with teachers' perception. Perception is a particular attitude or a way of viewing something. In relation to this study, perception indicates any sort of views and ideas pre-service English "language teachers hold regarding the nature of language learning and teaching" (ibid.). In fact, every English language teacher brings certain beliefs and perceptions with them in the classroom. Therefore, exploring pre-service English language teachers' perceptions is an essential issue. As Johnson (1992) states "these beliefs should be specified as early as possible because they shape pre-service teachers' understanding of language teaching and learning as well as their practices (as cited in Capan, 2014). “Teachers' knowledge of grammar, the way they are trained to teach grammar and the way they are taught grammar are the most prominent factors impinging their beliefs about grammar instruction" (Teik, 2011, as cited in Capan, 2014). In this regard, this 
study is based on Piaget's (1952) cognitive theory as teaching is a cognitive activity (Farrell \& Particia, 2005). Similarly, as belief system is socially constructed through interactions with other individuals who are more knowledgeable and experienced, this study is also based on social constructivism or socio-cultural theory developed by Vygotsky (1978). Thus, I used these two major theories as a theoretical framework to explain the perceptions of pre-service English language teachers regarding teaching English grammar.

Cognitivism as a theoretical framework focuses on mental processes of people's perception, thought, beliefs, memory, etc. The cognitive theory states that people produce knowledge and form meaning based upon their experiences. Vygotsky is a cognitivist, but rejects the assumption made by cognitivists such as Piaget that it is possible to separate learning from its social context. Vygotsky considers cognitive development primarily as a function of external factors such as cultural, historical, and social interaction(Amineh \& Asl, 2015). Cognitivism is a set of beliefs about teaching and learning, which helps to explain the perspectives on teaching grammar.

Social constructivism is a theory that examines the knowledge and understandings of the world developed jointly by individuals. It focuses on an individual's learning that takes place because of his or her interactions in a group in a social setting. This theory assumes that understanding and meaning are developed in coordination with other human beings (Amineh \& Asl, 2015). Social constructivists assert that knowledge is constructed through interaction with others.

Vygotsky states that cognitive growth occurs first on a social level, and then it can occur within the individual. In the words of Kim (2001), "Social constructivism emphasizes the importance of culture and context in understanding what occurs in society and constructing knowledge based on this understanding". Social constructivism represents "knowledge as a human product" (Kim, 2001) in the sense that knowledge is constructed in terms of the socio-cultural environment. Individuals can create meaning when they interact with each other and with the environment they live in.

My study is best supported by Piaget's cognitive theory, as teaching is taken as a cognitive activity, and perception is a mental process. Similarly, as belief system is socially constructed through interactions with other individuals who are more knowledgeable and experienced, this study is also based on social constructivism or socio-cultural theory as viewed by Vygotsky. Constructivism "suggests that humans construct knowledge and meaning from their experiences"(Bada, 2015). In this study, I investigated how pre-service English language teachers perceive teaching grammar as a formal classroom instruction and how their view acts as a social construct as Vygotsky suggests.

Pre-service English language teachers come to teacher education programme with certain prior experiences, perceptions, knowledge and beliefs about teaching and learning in general, and about teaching grammar in particular. Therefore, "preservice teachers' prior knowledge and beliefs have an effective role in developing them as teachers"(Dikici, 2012). In the teaching of grammar, pre-service English language teachers are expected to have their own beliefs and perspectives, which are reflected upon their prior experiences as students. In this regard, Piaget's cognitive theory and Vygotsky's social constructivism work as theoretical lens to explain my study. 
Likewise, this study is based on two contrasting views of grammar teaching: prescriptivism and descriptivism. Prescriptive grammar "states rules for what is considered the best or most correct usage" (Richards \& Schmidt, 2010), whereas descriptive grammar "describes how a language is actually spoken and/or written, and does not state or prescribe how it ought to be spoken or written" (ibid.).Based on the school of linguistic structuralism, descriptive linguistics founded by Bloomfield and Sapir is the modern concept of grammar teaching.

Similarly, this study is also supported by Aristotle's inductive-deductive approaches of reasoning. Deductive reasoning follows general to specific procedure, whereas inductive reasoning moves from specific to general procedure. Deductive and inductive reasoning are often equated with 'top-down' and 'bottom up' approaches respectively. These two approaches have been applied to grammar teaching and learning." A deductive approach starts with the presentation of a rule and is followed by examples in which the rule is applied", whereas "an inductive approach starts with some examples from which a rule is inferred"(Thornbury, 1999, p.29).Thus, a deductive approach involves the learners being given a general rule (rule-driven), which is then applied to specific language examples and consolidated through practice exercises. An inductive approach involves the learners observing patterns and working out a 'rule' (rule-discovery) for themselves before they practise the language.

Second or foreign language teachers are great consumers of grammar. They are mainlyinterested in pedagogical grammar, a grammar developed for learners of a foreign language, for their teaching in the classroom. In second or foreign language teaching, there is an extensive literature on pedagogical grammar. Pedagogical grammar is defined as "the types of grammatical analysis and instruction designed for the needs of second language students" (Odlin, 1994, as cited in Bourke,2005). Various linguistic theories have greatly influenced language teaching theories, and teaching grammar is just one part of language teaching. Until now in the history of linguistics, the three main stages of linguistic theories that have existed are traditional grammar, structuralism and functionalism (Xia, 2014). However, Bourke (2005) considers five main schools of English grammar that can be adopted in the context of ESL/EFL classroom: traditional prescriptive grammar, structuralist applied grammar, modern descriptive grammar, Chomskyan generative grammar, and Hallidayan systemic functional grammar. These theories of grammar are closely related to each other and have generated the change of language teaching trends. English language teachers should know and decide which kind of grammar is best suited to their pedagogic purpose and domain.

"Grammar for teaching purposes has to go beyond reference grammar and involve learners in 'grammaring', i.e. applying their grammar in various contexts of use" (Bourke, 2005). In this regard, modern descriptive grammar, which is structural in nature, seems to be quite suitable to support my research study. To be more specific, descriptive structural grammar helps my study understand the pre-service teachers' perspectives about teaching English grammar. Descriptive grammar focuses on describing the language as it is used, not saying how it should be used. Thornbury (2006) talks about prescriptive grammar, descriptive grammar, pedagogical grammar and mental grammar, defining that "a descriptive grammar simply describes, in a systematic way, the rules that govern how words are combined and sequenced in order to form sentences in a given language" (p.92). Descriptive 
grammar relies on structural analysis in its application. It looks at grammar on "many levels: morpheme, word, phrase, clause, sentence, and text" (Bourke, 2005). For example, at the sentence level, each simple sentence is analysed into its constituent parts known as grammatical functions such as subject, verb, object, complement and adverbial. These higher-level units are then analysed into their phrasal elements, such as noun phrase, verb phrase, etc. Phrases, in turn, are analysed into word classes such as noun, adjective, determiner, etc.

Many studies have been done on grammar instruction, and pre-service teachers' perceptions and beliefs towards grammar and grammar teaching. Dikici (2012) examined pre-service English teachers' beliefs towards grammar studying at two Turkish Universities. The aim of his study was to look into pre-service English teachers' pedagogical beliefs towards grammar and itsteaching as well as their knowledge on the metalanguage of grammar. The findings revealed that although a great majority of the participants favour the use of metalanguage in teaching grammar, and support the deductivegrammar teaching practices, they themselves still have serious problems even with the most basic grammatical terminology.

Uysal and Yavuz (2015) studied about the pre-service teachers' attitudes towards grammar teaching, studying ELT in Balýkesir University. The findings in general showed that pre-service teachers show an affirmative attitude towards grammar teaching although they strongly believe that it should not be taught directly or overtly.

Aljohani (2012) surveyed grammar beliefs of in-service teachers with the aim of understanding the mental lives of nonnative English language teachers at the tertiary level. He tried to find out teachers' beliefs regarding the nature of grammar, importance of grammar learning and grammar instruction, along with gender differences between male and female inservice teachers. The research was a quantitative one with a cross-sectional design. The researcher used a selfcompletion questionnaire to collect data with a Likert scale. Results showed that teachers showed a good understanding of the nature of grammar. Moreover, they appreciated the importance of learning grammar to facilitate language learning. Further, teachers believed that form and meaning should be taught together; and it should be put in a meaningful context as in dialogues. The Form-Focused Instruction seemed as an appropriate teaching method that suits teachers' beliefs. Gender seemed to play no role regarding teachers' beliefs.

Kaçar and Zengin (2013) investigated the perceptions and classroom practices of Turkish pre-service teachers of English employing a quantitative research design. Findings and results showed that the student-teachers favoured benefiting from not only form-focused instruction and but also holistic, meaning-based approaches.

Capan (2014) investigated pre-service English as Foreign Language teachers' beliefs development about grammar instruction in a foreign language context through their initial teaching practices, and found that practicum course has made no changes in pre-service teachers' beliefs except for the role of conscious knowledge.

Grammar teaching has been a controversial issue for long due to ESL/EFL contexts. Therefore,"there is a growing need to explore how pre-service English teachers perceive grammar teaching in a variety of contexts" (Kacar \& Zengin, 2013). Teachers as humans have their own perception of the world in general and about teaching and learning language in particular. So having their own perceptions 
will have its direct impact on teaching and learning. This field of teacher cognition allows us to discover those implicit beliefs teachers have about learning and language teaching, particularly grammar teaching and learning. By discovering those beliefs, teachers' behaviours can be interpreted more effectively. Those behaviours are the actual classroom practices accomplished by teachers(Aljohani, 2012).

Overall, the area of teachers' perspectives and beliefs is a relatively abstract construct. Borg (2003) maintains that there is a dearth of research on teachers' beliefs with nonnative teachers of English. Therefore, the present study tries to compensate this deficiency by focusing on pre-service EFL teachers' perspectives on teaching grammar in a Nepalese context with nonnative teachers of English. In Nepal, little research has been done in this particular field. No researcher (to my knowledge) has tried to investigate the pre-service English language teachers' teaching perspectives, nor grammatical beliefs in Nepal. The studies we have discussed above were in the context of foreign countries. Moreover, all of them followed quantitative survey designs. Therefore, this study aims at exploring the pre-service English language teachers' perceptions on teaching grammar in the context of Nepal, following qualitative phenomenological research design.

\section{Methods}

\section{Research Design}

This study employs a phenomenological research design, which "describes the meaning for several individuals of their lived experiences of a concept or a phenomenon" (Creswell, 2007, p.57) with a focus "on the participants' perceptions of the event or situation" (Williams, 2007, p.69). So this research study is qualitative in nature in that it attempts to explore information about pre-service English language teachers' perceptions on the phenomenon of teaching grammar to the learners in the classroom in a formal way.

\section{Participants}

The participants of the study consisted of three pre-service teachers studying English at Master's level under education faculty at TU. Out of three pre-service English teachers, two were females (Participant A and Participant C) and one was male (Participant B), ranging in age from 22 to 25 years. They were all native speakers of Nepali. The pre-service English language teachers participating in the study were informed before, after and during the research process about the aims. The participants were affirmed to be volunteers in the study. The participants for this study were selected using purposive sampling technique.

\section{Tools}

The information collection instrument consisted of two parts, background interview and open-ended questions asked orally. The background interview interrogated the pre-service English language teachers about their name, level, gender and age. Open-ended interview mainly included five research questions of the study. The participants were asked to express their experiences and views regarding the teaching of English grammar to the learners. To conclude, the research was conducted qualitatively as the semistructured interview technique was used to gather information from the participants' point of view.

\section{Procedure}

The study was employed a two-step procedure: information collection and information analysis. In information 
collection, the participants were asked to express their experiences and views regarding the teaching of English grammar to the learners. All the information was collected by the researcher. In information analysis, the information obtained from each participant was coded, interpreted and analyzed. The irrelevant statements were excluded in the limits of the research question interrogating the background of the participants. Finally, information was discussed and conclusion was drawn.

\section{Results and discussion}

On the basis of the information collected from three pre-service English language teachers studying at M.Ed. at TU, I have drawn some findings or themes of the study. So this section presents the results of the qualitative data analysis about the teaching of grammar with the focus on the research questions: how is grammar viewed, why is grammar taught, how should grammar be taught to language learners, and to what extent should grammar be taught. The results of the qualitative analysis are reported in three themes: pre-service English language teachers' perceptions of teaching grammar, role of grammar in language, and method to be used for teaching grammar.

\section{Perceptions of teaching grammar}

Perceptions and beliefs can have tremendous effects on the process of learning and teaching. "It is necessary to have better insights into teachers' beliefs because they have clearly been seen as one of the crucial factors that affect teachers and their teaching activities" (Thu, 2009).

Regarding teaching of grammar, all three participants showed positive attitudes towards teaching grammar. In response to the question "What is your view regarding teaching English grammar?", Participant A (names are not used for their privacy) said, while teaching grammar in the classroom, teachers should understand interest and the level of the learners. This expression clearly indicates that pre-service English teachers have belief towards teaching English grammar and they perceive it in a positive way. This expression is in line with Piaget's cognitive theory.Participant A focuses on indirect grammar teaching. It means grammar teaching is descriptive rather than prescriptive. Grammar is at a state in which it is considered an essential element of language teaching.

The evolution in language teaching from Grammar Translation method towards a more communicative approach in teaching has also brought with it a great change in the way grammar is viewed and taught. Traditionally, grammar was considered solely as prescriptive; but now teachers have begun to view it in terms of its descriptive aspects as well. Richards and Schmidt (2010) define descriptive grammar asa grammar which describes how a language is actually spoken and/orwritten, and does not state or prescribe how it ought to be spoken orwritten while prescriptive grammar isa grammar which states rules for what is considered the best or most correctusage.Therefore, as prescriptive grammarians suggest, grammar teaching is often seen as establishing the 'correct' way of speaking and writing. With the advent of communicative approach, it has become clear in language teaching that grammar is viewed as a tool or resource to be used in conveying meaning and comprehending other people's messages. The participants viewed on teaching grammar descriptively. In this regard, the view of Participant A is quite contextual as she expressed while teaching grammar...the teacher should be context-sensitive.As Vygotsky suggests, teaching is a socio-cultural activity, teaching grammar in context is apt. 


\section{The role of grammar in language teaching}

The teaching of grammar has been playing a central role in second and foreign language classrooms. "Regardless of how important grammar is considered in language learning, grammar remains being one of the essential factors to master a language" (Thu, 2009). Ellis (2006) asserts that grammar has held and continues to hold a central position in language teaching. Grammar teaching has always been a mainstay in ELT all over the world due to its importance for the consolitation of language learning.

All the three participants focused on the teaching of grammar as they viewed that grammar plays a significant role in language teaching. Responding to the question "Why is grammar teaching important?", Participant A expressed:

While teaching language students should have knowledge about the grammar. If they have not the knowledge about the grammar, they can't... they are not able to produce the acceptable structures and they can't convey the exact sense. While expressing something, it's important.

She focused on teaching grammar for developing confidence of the learners in using language for communication. Therefore, the knowledge of grammar is important.

Participant B expressed similar view saying that:

While learning language, this grammar is very essential, this grammar is very essential, so all the levels this is included and regarding for the language...we need to learn grammar and that must be very essential.
Participant B emphasized that teaching grammar is very important; it is indicated by the repetition of thephrase "very essential' three times. Moreover, as he expressed, it can be inferred that grammar is included at all levels in our education system, from school level to even master level.

Similarly, Participant C opined that:

Teaching grammar is one of the most essential part of the teaching learning strategies without grammar teaching learning is not effective... and it is interrelated with each other...teaching learning activities and grammar are interrelated.

This expression clarifies that grammar is the integral part of teaching learning activities. When the teachers have to teach or conduct activities for learning in the classroom, there is the use of grammar. Grammar is equated with the correct use of language in this context.

Participant C viewed:

Grammar is the backbone of language because...without grammar, we can't, students can't improve reading skill also, writing skill also then the speaking skill also then only the listening skill is not appropriate for students and it is not only used, so it is most important.

This expression indicates that teaching grammar is also helpful in developing the language skills such as reading, writing and speaking. As Participant B said grammar makes language very accurate which is essential to transfer the willing or to communicate effectively and to standardize the communication to make intelligible to the listener, so it's of course essential.

Thus, all three participants gave much more focus on teaching grammar due to its 
benefits in learning language for effective and accurate use in both spoken and written communication.

Many linguists and researchers have given support to grammar instruction in ESL and EFL language teaching and learning. For example, the communicative competence model of Canale and Swain(1980) clearly illustrates the significance of grammar. Without grammar, learners can communicate effectively only in a limited number of situations. In addition,Ellis (2002), Larsen-Freeman (2003) strongly support the teaching of grammar.

From the above perspectives given by three participants, it is obvious that grammar is now part of language teaching. In this regard, asCelce-Murcia(1991) says, grammar instruction should be contentbased, meaningful, contextualized and discourse based rather than sentencedbased.

\section{Deductive or inductive instruction?}

There are mainly two approaches to acquisition of grammar in teaching second or foreign languages: inductive and deductive. When grammar is taught inductively, a teacher allows students to induce and formulate a rule by themselves (Thornbury,1999). In deductive approach of teaching grammar, a teacher provides a clear grammar rule with relevant examples. As Nesic and Hamidovic (2015) claim," The deductive method is easier to apply than the inductive one, leaving little space for mistakes, provided it is explained in a correct and precise way".

While the participants were asked how grammar should be taught, they gave changing opinions. They said that they were taught grammar through deductive method at school and still teachers use deductive method. In this regard, to quote Participant A, in the context of Nepal, teachers especially teach grammar through the deductive approach. And to quote Participant $\mathrm{C}$, in our age...teachers teach only formula of the grammar... then there are not in practical way. These two participants meant that they were taught in a deductive way while they were taught grammar at school level. As Vygotsky suggests, teachers construct their own understanding about teaching grammar through experiencing and reflecting on those experiences.Teaching grammar has become a social 'convention' (Lewis, 1968) in the context of Nepal as teachers mostly use deductive method of teaching grammar due to its tradition since long.'Deductive learning occurs when a rule or generalization is first presented to the learners, and then they go on to apply it in practical activities' (Thornbury, 2006). Contrary to this, in an inductive approach, 'the learners themselves generalize the rule from examples, before practising it'(ibid.).

Now they have different opinions regarding how grammar should be taught. All of them preferred inductive method of teaching grammar. To quote Participant A again:

Teacher should use the communicative approach...if teachers develop rapport between the students and motivate them and encourage them, they can easily produce the acceptable structures while expressing their views...inductive will be the best and the teacher should provide the students centred activities...we can focus grammar through the indirect teaching with teacher can use the indirect approach, indirect grammar teaching methods and give the free environment and friendly environment in the classroom and the indirect is the grammar, grammatical structures and the grammatical correctness of the learners but through different language skills and the aspects.

Her expressions clarify that grammar should be taught indirectly, inductively 
involving students in communicative activities. This way is the practical way of teaching grammar. Again to quote Participant C:

Somehow if grammar is practical way then it teaches effectively but only the rules is not effective for students... with interaction between the teacher and the students it's more effective in grammar teaching. Only the lecture method is not suitable for grammar teaching...inductively it's the best in the grammar teaching because without interaction grammar teaching is impossible...inductively way is the learning by doing then practical way then teaching in context then it is effective.

The ideas expressed above suggest that grammar teaching should be practical through interaction and in context. Only the rules given to students through lecture method cannot be effective. This is in line with constructivism as the learners can construct meaning of grammar if they are provided social and cultural contexts of learning grammar in an interactive way.Social constructivists assert that knowledge is constructed through interaction with others. Therefore, learners can easily learn grammar if they are provided interactive environment in different contexts.

\section{Conclusion}

This article has explored the perceptions of pre-service teachers of English towards teaching English grammar to the learners in a formal classroom setting. Pre-service English language teachers consider grammar as an efficient way of learning a language and state that teaching grammar is quite essential for developing language skills. Pre-service teachers' attitudes towards grammar are generally positive and they are in favor of teaching grammar integrating with skills in a formal way in the classroom. The participants state that grammar teaching promotes accuracy at the expense of fluency. They believe the theory that if learners discover rules on their own, they can acquire them better. They are under the impression that contexts and interaction that serve communication can promote grammar learning and think it is appropriate to teach grammar in a context-sensitive way. They are in favour of using inductive method of teaching grammar while they accept that explicit grammar teaching works better for them in an academic study though they were taught deductively while studying at school.The participants criticize that English teachers still use traditional deductive method while teaching grammar without involving learners in the activities.

The findings of this study have great pedagogical implications for the English language teachers. As it indicates, teaching grammar is essential because it supports other language skills. Like listening, speaking, reading and writing, grammar has been taken as a skill to be developed for the effective use of language both in spoken and written forms. For this, inductive method of teaching grammar has to be applied by the teachers to involve the learners in learning.

In this study, I have just explored the preservice teachers perceptions about teaching English grammar in the formal classroom setting. How in-service teachers perceive teaching English grammar in the context of Nepal can be another area of research.

From the views that I got from the preservice teachers, what I feel is that teaching grammar is essential for the consolidation of language skills. Regarding how it has to be taught, my feeling is that for the beginners inductive approach is better but in higher levels, it is best to use deductive approach as the learners of higher level prefer rules directly. This is what I have experienced from my teaching up to now. 


\section{References}

Aljohani, M.A. (2012). Grammar beliefs of in-service teachers.British Journal of Arts and Social Sciences, 11(1), 96-108. Retrieved from https:// www.researchgate.net/publication/ 277711577_Grammar_Beliefs_of_inService_Teachers

Amineh, R. J., \& Asl, H. D. (2015). Review of constructivism and social constructivism.Journal of Social Sciences, Literature and Languages, 1(1), pp. 9-16. Retrieved from http://bluea p . or g / j / L i s t / 4 / i s s / volume $\% 201 \% 20(2015) /$ issue $\% 2001 /$ 2.pdf

Bada, S. O. (2015).Constructivism learning theory: A paradigm for teaching and learning. IOSR Journal of Research $\mathcal{E}$ Method in Education (IOSR-JRME), 5 (6 ), pp. 66-70. Retrieved from https:/ /pdfs.semanticscholar.org/1c75/ 083a05630a663371136310a30060a 2afe4b1.pdf

Borg, S. (2003). Teacher cognition in language teaching: A review of research on what language teachers think, know, believe, and do. Language Teaching, 36 (2), 81-109. Retrieved from http:/ / eprints.whiterose.ac.uk/ 1652/1/borgs1_Language_Teaching_ 36-2.pdf

Bourke, J.M. (2005). The grammar we teach. Reflections on English Language Teaching, 4, 85-97. Retrieved from https://pdfs.semanticscholar.org/ e597/4cdf3867ec781afb585f7653a 56d79f074de.pdf

Burgess, J., \& Etherington, S. (2002). Focus on grammatical form: explicit or implicit? System, 30, 433-458. Retrieved from https:// teletandemitaliano.wikispaces.com/ f i l e / v i e w / B UR G E S S focus+on+grammatical+ form.pdf

Burgo, C. (2015). Grammar teaching approaches for heritage learners of Spanish. Revista de investigación e innovación en la clase de idiomas, 24, 114. Retrieved from https:// csctfl.wildapricot.org/resources/ D o c u m e n t s / 2015 R e port / Chapter\%2011.pdf

Busch, D. (2010). Pre-service teacher beliefs about language learning: The second language acquisition course as an agent for change. Language Teaching Research, 14 (3), 318-337. Retrieved from http://journals.sagepub.com/ doi/pdf/10.1177/1362168810365239

Canale, M., \& Swain, M. (1980). Theoretical basis of communicative approaches to second language teaching and testing.Applied Linguistics, 1 (1), 1-47. Retrieved from https:// www.researchgate.net/publication/ 31260438_Theoretical_Bases_of_ Communicative_Approaches_to_Second_ Language_Teaching_and_Testing

Çapan, S. (2014). Pre-service English as a foreign language teachers' belief development about grammar instruction. Australian Journal of Teacher Education, 39 (12). Retrieved from http://ro.ecu.edu.au/ajte/ vol39/iss12/9

Celce-Murcia, M. (1991).Grammar pedagogy in second and foreign language teaching.TESOL Quarterly, 25 (3), 459-477. Retrieved from http:/ / a pi.nin g. c o m / fil e s / ls7O*qnA7CvUcCzb0abEBntOC6BegVva DHf1Rt5jAFiRMtwar4HyUBvfSHGMjyzN*3wLvPo08J4VP6Fpbrmx 9hR85asEWgs/CelceMurcia.pdf 
Cowan, R. (2008). The teacher's grammar of English. Cambridge: Cambridge University Press.

Creswell, J.W. (2007). Qualitative inquiry and research design: Choosing among five approaches (2nd ed.). Thousand Oaks, California: Sage Publications, Inc.

Dikici, I.Z. (2012). Pre-service English teachers' beliefs towards grammar and itsteaching at two Turkish universities.International Journal of Applied Linguistics $\mathcal{E}$ English Literature, 1 (2), 206-218. Retrieved from http://www.journals.aiac. org.au/index.php/IJALEL/article/ view $/ 718 / 648$

Doff, A. (2000). Teach English: A training course for teachers (14th ed.). Cambridge: Cambridge University Press.

Ellis, R. (2002). Grammar Teaching Practice or ConsciousnessRaising?InJack C. Richards \& Willy A. Renandya (Eds.). Methodology in language teaching. Cambridge: Cambridge University Press.

Ellis, R. (2006. Current issues in the teaching of grammar: An SLA perspective. TESOL Quarterly, 40 (1), 83-107. Retrieved from https:// www.academia.edu/1753904/ Current_issues_in_the_teaching_of_ grammar_An_SLA_perspective

Farrell, T.S.C., \& Particia, L.P.C. (2005). Conceptions of grammar teaching: A case study of teachers' beliefs and classroom practices. Teaching English as a Second or Foreign language, 9 (2), 1-13. Retrieved from https:// files.eric.ed.gov/fulltext / EJ1065837.pdf
Johnson, K. E. (1992). The relationship between teachers' beliefs and practices during literacy instruction for non-native speakers of English.Journal of Reading Behaviour, 24 (1), 83-108. Retrieved from http:// journals.sagepub.com/doi/pdf/ $10.1080 / 10862969209547763$

Kaçar, I. G., \& Zengin, B. (2013). Perceptions of pre-service teachers of English towards grammar teaching in the Turkish context.The Journal of Language and Linguistic Studies, 9 (1), 50-80.retrieved from http:// www.jlls.org/vo19no1/50-80.pdf

Kim, B. (2001). Social constructivism. Emerging Perspectives on Learning, Teaching, and Technology, 1-8. Retrieved from http:// relectionandpractice. pbworks.com/ f/Social\%20Constructivism.pdf

Lakhoua, L. (2016). To Teach or Not to Teach Grammar: a Controversy? Online Journal: Revisiting the Communicative Approach, 7th Issue. Retrieved from http://web.aou. edu.lb/images/stories/lebanon/ Research/CALR/issue7/articles/ CALR\% 207\%20article\% 204.pdf

Larsen-Freeman, D. (2001). Teaching grammar. In M. Celce-Murcia (ed.), Teaching English as a second or foreign language (3rd ed., pp. 251-66). Boston, MA: Thomson/Heinle. Retrieved from https://www.uibk.ac.at/anglistik/ staff/freeman/course-documents / tesfl_-_teaching_grammar.pdf

Larsen-Freeman, D. (2003).Teaching Language: From grammar to grammaring. Boston: Heinle \& Heinle.

Lewis, D. (1968). Convention: A philosophical study. Cambridge: Harvard University Press. Retrieved from 
http:/ / www.princeton.edu / harman/Courses/PHI534-2012-13/ Nov26/lewis-convention1.pdf

Mart, C.T. (2013). Teaching grammar in context: Why and how? Theory and Practice in Language Studies, 3, (1), 124-129. Retrieved from http:// www.academy publication.com/ issues/past/tpls/vol03/01/18.pdf

Nesic, I.D., \& Hamidovic, K.C. (2015). Teaching English grammar: Efficiency of inductive and deductive approaches: Students' perceptions. Retrieved from http://scindeks-clanci.ceon.rs/data/ pdf / 0354 - 3293 / 2015 / 0354 32931503189 N.pdf

Pullum, G.K. (2006). Ideology, power, and linguistic theory. Retrieved from https:/ / people.ucsc.edu/ pullum/ MLA2004.pdf

Rahman, A.M.A., \& Rashid, R.A. (2017). Explicit and implicit grammar instructions in Higher learning institutions.English Language Teaching, 10 (10). Retrieved from https:// files.eric.ed.gov/fulltext / EJ1153877.pdf

Richards, J.C., \& Schmidt, R. (2010). Longman dictionary of language teaching and applied linguistics ( $4^{\text {th }}$ edition). Harlow, England: Pearson Education Limited.

Richards, J.C., \&R enandya, W.A. (2002). Methodology in language teaching: An anthology of current practice. Cambridge: Cambridge University Press.

Thornbury, S. (1999). How to teach grammar. England: Pearson Education Limited.
Thornbury, S. (2006). An A-Z of ELT. London: Macmillan Education.

Thu, T.H. (2009). Teachers' perceptions about grammar teaching. Retrieved from https:/ / files.eric.ed.gov/fulltext/ ED507399.pdf

Ur, P. (1999). Grammar practice activities: A practical guide for teachers (12th ed.). Cambridge: Cambridge University Press.

Uysal, N.D., \& Yavuz, F. (2015).Pre-service teachers' attitudes towards grammar teaching.Procedia - Social and Behavioral Sciences, 191, 1828 - 1832. Retrieved from https:// www.sciencedirect.com/science/ article/pii/S1877042815026130

Widodo, H.P. (2006). Approaches and procedures for teaching grammar.English Teaching: Practice and Critique, 5 (1). Retrieved from https:/ / edlinked.soe.waikato.ac.nz/ research / files / etpc/files / 2006v5n1nar1.pdf

Williams, C. (2007). Research methods. Journal of Business and Economic Research, 5 (3), 65-72.

Thornbury, S. (1999). How to teach grammar. England: Pearson. 


\section{Appendix A}

\section{Interview Guideline Questions}

1. What is your name?

2. Where are you from?

3. At which semester of M.Ed. are you studying?

4. Were you taught English grammar at school level?

5. How do you perceive teaching English grammar?

6. Do you think that grammar teaching is important to the learners at school level?

7. Why is grammar teaching important?

8. How do you think that grammar should be taught? Directly or indirectly?

9. What can be the best way of teaching grammar?

10. Can we teach grammar in contexts?

11. Why do you think that inductive approach of teaching grammar is better?

12. How were you taught grammar at school level?

13. Don't you think that deductive approach of teaching grammar is better? Why?

14. How much focus should be there in teaching grammar?

15. If you have to teach grammar, then how will you teach: deductively or inductively?

\section{Contributor}

Mohan Singh Saud is currently an M.Phil. scholar at Graduate School of Education, Tribhuvan University, Nepal. He has been teaching English from plus two to Master's level at Kailali Multiple Campus, Dhangadhi, Nepal since 2004. He has published some books including school level English series, some journal articles. His areas of interest include grammar teaching, professional development, English medium instruction (EMI), mother tongue-based medium of instruction, linguistic diversity and globalization 